\title{
The Impact of Gender Disparity of Physician and Patient [Letter]
}

\author{
Yingxin Gong $\mathbb{D}^{1, *}$, Yuxuan $\mathrm{Wu}^{2, *}$, Lu Zhang' \\ 'Cervical Diseases Center, Obstetrics and Gynecology Hospital of Fudan University, Shanghai, People's Republic of China; ${ }^{2}$ Anhui Medical University, \\ Hefei City, Anhui Province, People's Republic of China \\ *These authors contributed equally to this work \\ Correspondence: Lu Zhang, Cervical Diseases Center, Obstetrics and Gynecology Hospital of Fudan University, No. I28 Shenyang Road, Yangpu \\ District, Shanghai, 2000II, People's Republic of China, Email zhangluII21@I26.com
}

\section{Dear editor}

We read this study ${ }^{1}$ with great interest. The authors retrospectively evaluated the cohort of Canadian administrative data. They concluded that, age and gender concordance were not associated with statin adherence, while gender concordance might play a role.

This is an interesting topic about the gender disparity of physician and patient in the clinical practice.

1. The authors have demonstrated the difference of various factors associated with the adherence of statin usage. One might be lacking is the severity of the diseases, the association of clinical parameters, such as blood lipid panel test results.

2. This study might need to emphasize the proportion of the physicians' gender types in the study. In some specialty, the gender disparity of physicians is so tremendous which might be a causative factor contributing to the statistically significance of gender concordance.

Interestingly, a study ${ }^{2}$ by researchers from Harvard University and other institutions analyzed 500,000 cases of acute myocardial infarction sent to the hospital in Florida from 1991 to 2010. They found that gender matching between patients and treating physicians was significantly associated with mortality. That is to say, female patients had significantly higher than average survival rates when first aid was administered by a female physician. This could lead to a conclusion that increasing the proportion of female doctors is a top priority.

We are still skeptical of this conclusion, partly due to the retrospective nature of the study and possible bias of gender disparity of physicians.

Afterwards, the authors have contributed for the data of patient adherence of statin usage. The conclusion comforts either the prescribers and patients for future clinical practice.

\section{Disclosure}

The authors report no conflicts of interest in this communication.

\section{References}

1. Yao S, Lix L, Teare G, Evans C, Blackburn D. The impact of age and gender concordance between patients and physicians on medication adherence: a population-based study. Patient Prefer Adherence. 2022;16:169-178. doi:10.2147/PPA.S340573

2. Greenwood BN, Carnahan S, Huang L. Patient-physician gender concordance and increased mortality among female heart attack patients. Proc Natl Acad Sci USA. 2018;115(34):8569-8574. doi:10.1073/pnas.1800097115 
Dove Medical Press encourages responsible, free and frank academic debate. The content of the Patient Preference and Adherence 'letters to the editor' section does not necessarily represent the views of Dove Medical Press, its officers, agents, employees, related entities or the Patient Preference and Adherence editors. While all reasonable steps have been taken to confirm the content of each letter, Dove Medical Press accepts no liability in respect of the content of any letter, nor is it responsible for the content and accuracy of any letter to the editor.

\section{Publish your work in this journal}

Patient Preference and Adherence is an international, peer-reviewed, open access journal that focusing on the growing importance of patient preference and adherence throughout the therapeutic continuum. Patient satisfaction, acceptability, quality of life, compliance, persistence and their role in developing new therapeutic modalities and compounds to optimize clinical outcomes for existing disease states are major areas of interest for the journal. This journal has been accepted for indexing on PubMed Central. The manuscript management system is completely online and includes a very quick and fair peer-review system, which is all easy to use. Visit http://www.dovepress.com/testimonials.php to read real quotes from published authors.

Submit your manuscript here: https://www.dovepress.com/patient-preference-and-adherence-journal 